\title{
POST-APARTHEID REFLECTIONS ON CRITIQUE, TRANSFORMATION AND REFUSAL
}

by Joel SM Modiri*

\author{
Introduce a little anarchy \\ Upset the established order \\ And everything becomes chaos. \\ (The Joker $)^{1}$
}

\section{Introduction: Refusal in snapshots}

In this article I engage with the notion of refusal, as introduced by Karin Van Marle, to post-apartheid jurisprudence as a way through which to think of life, death, law and politics against the backdrop of poverty, social misery, disease, oppression and prejudice. ${ }^{2}$ She proposes that we consider refusal firstly as a possible mode of critical thinking and theorising but ultimately also as an alternative approach to law and jurisprudence. ${ }^{3}$ For Van Marle, what lies at the heart of refusal is the 'idea of unexpectedness that breaks with the formality and predictability of law'4 - an unexpectedness that could disclose new directions for thinking about and doing law. In Van Marle's own words:

The project on refusal and risk within the South African post-apartheid context involves a rethinking of the prevalent ideas on transformation, transformative constitutionalism and law. The aim is to call for a refusal of instrumental reliances on knowledge. Refusal is an action in the limit, action imbued with reflection. A risking law arises because of the refusal traditional and unreflective approaches. ${ }^{5}$

* Second year LLB, University of Pretoria. I am grateful to Karin van Marle for her continued support, mentorship and encouragement. I am also grateful to Isolde de Villiers for her thoughtful and incisive comments on this piece - in the process helping me to clarify my thoughts and improve the form and substance of this article. Many of the thoughts shared in this paper have greatly benefitted from discussions with Duard Kleyn, Albie Sachs, Dennis Davis, Pierre de Vos, Drucilla Cornell, Christof Heyns and Stu Woolman. Finally, I want to thank Petronella Kruger, Alfred Moraka and Serena Kalbskopf for always pressing me to think deeper and differently about life and law.

1 Christopher Nolan (dir.) The dark knight (2008).

2 K van Marle 'Laughter, refusal, friendship: thoughts on a "jurisprudence of generosity"' (2007) 18 Stellenbosch Law Review 194. See the book review: M Slabbert \& APJ Roux 'Human rights concern much more than only racial differences and discrimination' (2010) 75 Koers: Bulletin for Christian scholarship $683-688$

3 K van Marle 'Introduction: refusal, risk, liminality' in K van Marle (ed) Refusal, transition and post-apartheid law (2009) 13.

4 n 3 above, 1.

5 n 3 above, 13. 
As a point of departure, perhaps an intriguing aspect of the notion of refusal is its presentation. Both Wessel Le Roux ${ }^{6}$ and Stu Woolman ${ }^{7}$ note how, in conceptualising the notion of refusal, Van Marle resolutely turns away from conventional, pedantic legal writing styles. It is indeed the avoidance of gratuitous over-quoting of 'legal' sources, the absence of mechanical and uninspired interpretations, and the defiant and critical treatment of the pervasive institutions of law and human rights that makes refusal such a compelling notion. In refusing to write in the dry, doctrinal and masculine style expected of law professors, Van Marle beckons the first of many acts of refusal.

Refusal provides a new model for theorising and thinking about issues of transformation, reconciliation and inequality in ways that are radically different to, and critical of, formalist and liberal approaches that operate within the strict economy of law and human rights. In this way, it offers alternative perspectives on human agency, subjectivity and life under law in the 'new' South Africa. It displaces the hegemonic order, 'setting up an impenetrable distance between that order and itself.' 8 follows: ${ }^{9}$

The importance of considering refusal is set out by Van Marle as

In South Africa it seems as if transformation, socio-economic reparation and other social problems like poverty, violence and disease are addressed mostly through law and human rights. But, as is often argued and exposed, law and human rights are lacking in the capacity to effect real change. How can we find different ways to approach these issues in the face of the pervasiveness of law and human rights? I would like to ... ask ... to what extent the "public" face of the new legal order (human rights and constitutionalism) is translated into the "private".

In my view, refusal marks a major shift in legal theory, primarily because of its concern with the possibilities and simultaneous impossibilities of another political community, another law and a more egalitarian set of relationships between people. Situated within a post-apartheid context, refusal opens up legal discourses to social, political, and ethical issues in people's day-to-day lives. Woolman highlights two aspects of refusal that are significant for this discussion: ${ }^{10}$

First, genuine reformation is more likely to be found in the day-to-day interactions and relationships that take place beyond the law, beyond normal politics and beyond revolution. Secondly, it is a perfectly

W Le Roux 'Six (individually-named) notes on the counter-aesthetics of refusal' in Van Marle (ed) (n 3 above) 58.

7 S Woolman 'On rights, rules and relationships: a reply to Van Marle's "jurisprudence of generosity"' (2007) 18 Stellenbosch Law Review 508.

8 A Cavarero In spite of Plato: A feminist rewriting of ancient philosophy (1995) 17.

9 n 2 above, 194

10 n 7 above, 516. 
reasonable response to the world as it is to turn away from law, politics and revolution - because they have failed to deliver - and to embrace 'solitude' - and a refusal to give the processes of law, politics and revolution our tacit imprimatur of approval.

It was in fact Woolman who coined the term 'ethic of refusal' to describe the objects of Van Marle's jurisprudential project. At the core of this ethic is a concern with context and particularity, ${ }^{11}$ with 'embodiedness' and 'embededness,' 12 and with voices previously silenced and excluded from the public space. Van Marle eschews liberal, elitist and positivistic accounts of law and draws from the worlds of politics, philosophy, literary criticism and film theory to warn of the dangers of the over-enthusiastic embrace of and trust in law and human rights.

After reading and re-reading Van Marle's thoughts on refusal, it is easy to come away with the impression that she is flirting with a nihilistic, defeatist idea of law. Admittedly, that would be a plausible reading but also an unreflective and inattentive reading. To my mind, refusal does not refuse law; it challenges lawyers, scholars and judges to take risks - it thus refuses only a risk-free, predictable, mainstream conception of law.

Refusal calls for a risking law - one that refuses cautious modes of analysis and takes bold risks, experiments with possibilities and new approaches, and goes beyond expected confines in order to address the 'position of a concrete embodied person ...'. ${ }^{13}$ A risking law is one that is undaunted by being faithful to a certain notion of analytical rigour, theoretical analysis and interpretive tradition.

The connection between risk and law is highlighted in Karl Klare's call for the refusal of formalist approaches to legal interpretation and his urging of legal practitioners, academics and judges to take up the challenge of 'transformative constitutionalism': ${ }^{14}$

The New South Africa has a Constitution with massively egalitarian commitments superimposed on a formalistic legal culture without a strong tradition of substantive political discussion and contestation through the medium of legal discourses. An opening of transformation requires South African lawyers to harmonise judicial method and legal interpretation with the Constitution's substantively progressive

11 K van Marle 'Law's time, particularity and slowness' (2003) 19 South African Journal on Human Rights 245.

$12 \mathrm{~K}$ van Marle 'The universe is made of stories not atoms' (2000) 2 Phronimon 346. For these purposes 'embodiedness' refers to a certain completeness that all human beings should enjoy through freedom, agency and moral sovereignty. 'Embeddedness' refers to a rootedness and individual selfhood that comes from one's identification with and membership within a specific community/ies.

$13 \mathrm{~K}$ van Marle 'Transformative constitutionalism as/and critique' (2009) 20 Stellenbosch Law Review 291.

14 K Klare 'Legal culture and transformative constitutionalism' (1998) 14 South African Journal on Human Rights 188. 
aspirations. The burden of my argument is that law and legal practices can be a foundation of democratic and responsive social transformation, but that this requires us to evolve an updated, politicised account of the rule of law.

This challenge demands that we refuse the continuance of the apartheid legal culture. If we fail to take up this challenge, the Constitution, and all the concomitant theoretical perspectives and modes of legal reasoning meant to support it, will remain a vicious rumour to the black people who are caught up in the structural violence of poverty and dispossession; to the women who are trapped in abusive marriages and terrorised by rapes and harassment; to the poor communities with no access to clean running water; to the hungry and homeless without food and blankets in the cold winters; to the children who don't go to school and to the refugees who are beaten, violently deported and killed every year in South Africa. Refusal, in this context, could then be understood as taking up Klare's challenge of transformative constitutionalism. In fact, I would suggest that when read together, Van Marle's ethics of refusal and Klare's transformative constitutionalism make another point: they argue for an approach (or approaches) that acknowledges and works with the deeply political and ideological underpinnings of law; that can counter and enhance the business-as-usual mindset of the postapartheid legal community.

As can be seen from the introduction above, refusal is a loaded and complex concept. It can be understood in many ways and interpreted from many different angles. It has many contingent meanings and holds multiple possibilities for political thought and action. In what follows, I reflect on these meanings and possibilities. A comprehensive summary of Van Marle's article is not provided because I proceed from the assumption that the reader is familiar with the article and/or book on refusal. ${ }^{15}$ Where this assumption is misplaced, readers are urged to read the article. The aspects highlighted here may not necessarily be the most important aspects for others. The arguments in this article will be framed around three signal forms of refusal: (1) 'refusal as critique' discusses refusal a critical approach to law and legal theory; (2) 'refusal as limit and possibility' explores how by engaging with the limits of law, refusal beckons alternative approaches and new possibilities and (3) 'refusal as performative' examines the role of citizens and social movements in enacting their own refusals and practices of resistance against hegemonic meanings and institutions (such as law, capitalism etc). This article offers no easy answers or facile solutions and does not claim to have a prophetic comprehension of the meaning, demands and objects of an ethic of refusal. Instead, an attempt is made to 
briefly sketch the key themes and animating features of refusal and contribute to an authentic discourse on law, human agency and critique.

\section{Writing refusal - refusal as critique}

The notion of refusal can quite plausibly be read as a postscript to and side-effect of Van Marle's earlier writing on (the absence of) 'action, thinking and revolt ...'. ${ }^{16}$ The crux of Van Marle's argument and the anchor of her scholarship is that South African society is characterised by an overwhelming over-reliance on law, human rights and constitutional discourse. As a result, this has lead to a dire absence of conscious political action, ethical thought and critical revolt within politics, law and critique. Law is not politics precisely because it is unable to contain political action and revolt. ${ }^{17}$ Refusal is thus an 'ethical engagement with the limits of law' 18 and invites politics, risk and liminality.

Admittedly, the sometimes thick soup of Van Marle's metaphysical prose is not for the faint-hearted, nor is it for the dogmatic and uncritical. It is for those who, in the present climate of constitutional optimism and an unquestioning faith in the rule of law, still dare to allow some scepticism and radical critique to break into flight and disrupt legal discourses in ways that expose the conservative, patriarchal, and white supremacist underpinnings of those discourses. Seeking to critically articulate her frustrations with a society overtaken by the grand-narrative of the Constitution and a proceduralised and institutionalised human rights system, Van Marle challenges Christof Heyns' struggle theory of human rights. With this critical review of Heyns' theory, Van Marle wanted to show: ${ }^{19}$

$[T]$ he reductions that occur when coupling politics with law (struggle with rights) and humanity and human life with legitimacy (human with legitimate). In close proximity to the above is also the ethical notion of responsibility that is reduced to a mere instrumental responsibility that corresponds with rights. Ultimately I lament that passion and the passion of the moment is limited and reduced to a tempered passion.

Van Marle 'Lives of action, thinking and revolt $-\mathrm{a}$ feminist call for politics and becoming in post-apartheid South Africa' (2004) 19 SA Public Law 572-604.

17 Van Marle \& Le Roux 'Introduction' in Van Marle \& Le Roux (eds) Post-apartheid fragments: law, politics and critique (2007) xii - xiii. This claim is also made by E Christodoulidis 'The suspect intimacy between law and political community' (1994) 80 Archiv für Rechts- und Sozialphilosophie 1-18 and J van der Walt 'The (im)possibility of two together when it matters' (2002) Journal of South African Law 462-477.

18 n 17 above, xiii.

19 n 16 above, 616 
For Heyns, '[o]ne way of looking at human rights is to see it as the flipside of the coin of legitimate resistance ...' ${ }^{20}$ He concretises this idea in the expression 'human rights/legitimate resistance' and 'legitimate resistance/human rights. ${ }^{21}$ Heyns, in what appears as an attempt to formulate a populist account of human rights, argues that 'behind human rights claims there is the possibility, if there are no reasonable alternatives, of resorting to self-help; and conversely, that for self-help to be legitimate ...' 22 Heyns contends that 'human rights serve as a countervailing force against state power' and that it is specifically its strong association with resistance that gives human rights such force and legitimacy. ${ }^{23}$

In terms of the struggle theory, rather than thinking of 'law [as] a command of a sovereign, backed by a threat' as was said by the positivist John Austin, it is better to think of 'human rights claims as demands of citizens, backed by a threat'- the threat of self-help; the threat of (legitimate) resistance; the threat of refusal to obey. ${ }^{24}$ In view of that, the bold assertion 25

... that rights are 'inalienable' does not imply that they cannot be taken away, but rather that should they be alienated they may be 'taken back', either by those whose rights have been violated or by others on their behalf.

Human rights, Heyns argues, are 'guides to action and triggers of resistance' and 'as such, human rights has a potentially revolutionary dimension ...'26 This revolutionary element is evidenced by the worldwide clampdown by authoritarian regimes on human rights activists.

It is Heyns' contention that human rights do not rely on recognition by the state - they are in fact minimum conditions for the existence of a state. If a state fails to protect the rights that are at the core of human existence, the duty to obey the state lapses, thus exterminating the very functioning of law: a balance between state power and civil compliance with state laws. ${ }^{27}$

He explains the foundation of or the reason for human rights as the 'common sense resolution' to 'never repeat the mistakes of the past ...' ${ }^{28}$ Consequently, the 'morality' of human rights is merely 'an attempt at long term rationality ...'.29 For him, 'practice underlies 
theory - not the other way around.' Historical events and human rights documents that contain the right to resistance are presented as proof of the struggle theory's credibility: the Magna Carta of 1215, John Locke's defence of the 'Glorious Revolution' of 1688, and the American Declaration of Independence of $1776 .{ }^{30}$ Accordingly, human rights are the 'ultimate guarantor of popular sovereignty ...'31 Bringing his arguments back to a South African context, Heyns finds resonance with his theory in Mahatma Gandhis' satyagraha (civil disobedience) and Nelson Mandela's words: 'the struggle is my life ...'32 He points to the Freedom Charter as 'the document that more than any other serves as a 'codification' of the struggle' and to the 1996 Constitution of South Africa as 'the culmination of the struggle.' 33 The above briefly captures some of the main tenets of the theory that 'human rights = legitimate resistance'.

As is clear here, the struggle theory is also concerned with the power and meaning of refusal in a different form - perhaps one which is more legalist and technical. In terms of the struggle theory, one can refuse to obey the law and refuse to do that which goes against one's 'fighting causes' or 'core interests' (such as the shared beliefs and values in a community or nation). The difference and problem is that the struggle theory is conditional and limited to attacks on conscience, infringement of first-generation rights and unacceptable material living conditions.

Struggle, civil disobedience and Heyns' conception of refusal can be allowed only in 'extreme cases' where it is 'justified' based on 'empirical evidence' whereas Van Marle's conception is open to all acts of refusal in the public and private sphere, in law and in politics. Van Marle, following Hannah Arendt and Julia Kristeva, is more concerned with constant questioning, political action, reflective thought and contestation of a non-violent but critical, lively and dialogical nature. Indeed, it is easy and natural in the present world context to become indifferent to and despondent about the interpretation and application of human rights. Not only have the greatest human rights violations taken (and continue to take) place in our time, but human rights have also lost their 'critical edge' by becoming the tool of governments and international organisations. ${ }^{34}$

Van Marle regards the main problem of the struggle theory to be its very grandiose style of argumentation. This is seen in the struggle theory's declaration to provide the 'ultimate foundation and explanation for human rights' and its claim to be able to settle all current and future tensions, debates and protestations on human

n 20 above, 17-20.

n 20 above, 17.

n 20 above, 22.

n 20 above, 21-22.

C Douzinas The end of human rights (2000). 
rights. ${ }^{35}$ Another point of critique is the strong emphasis Heyns places on a formal notion of legitimacy, as well as his heavy reliance on mostly Western history.

For Van Marle, the struggle theory 'relies on a modernist acceptance of rationality and human reason' and 'follows an abstract form of agency ...' ${ }^{36}$ Van Marle's uneasiness with the struggle theory is that it assumes a single history and asserts the possibility (and perhaps desirability) of 'one universal truth ...'37 Following Jean-Luc Nancy and Arendt, Van Marle contends that '[h]uman rights should be seen as a form of action, not a set of moral truths ...' 38 In her view, ' $[\mathrm{t}] \mathrm{o}$ concentrate on rights that are attached to politically passive and invisible legal subjects could lead to misdirection in our resistance to totalitarianism ...' ${ }^{39}$ In Van Marle's view, this 'is not true to the Arendtian tradition of active politics and the centrality of life and narrative ...' 40 This claim is supported in Arendt's conception of 'totalitarian lawfulness', which as Le Roux mentions, 'defines itself by the open defiance of positive laws and petty legality in favour of the direct reign of justice on earth. ${ }^{41}$ She questions how the struggle theory differs from natural law explanations for the origins of, and justification for, human rights. Still, Van Marle's bone of contention with the struggle theory is with its inability to contain, or even facilitate, post-apartheid politics because of its concern with reason, logic and rational knowledge. Further, according to the struggle theory, the eventual codification of human rights in international treaties and conventions and the entrenchment of human rights in domestic Constitutions marks the 'end of political struggle rather than its beginning.' 42 In this way, the possibilities for meaningful struggle and active and continuous politics is diluted, and perhaps even negated, by requirements of legitimacy and validation.

[T] he translation of struggle into rights, humanity into legitimacy, and politics, thinking and narrative into an economy of the private, puts a damper on action, thinking and revolt and a politics of becoming. ${ }^{43}$

Although it hints at the potential becoming of a politics of refusal, the struggle theory closes the space for refusal because the existence of law and human rights makes self-help (resistance and also, struggle

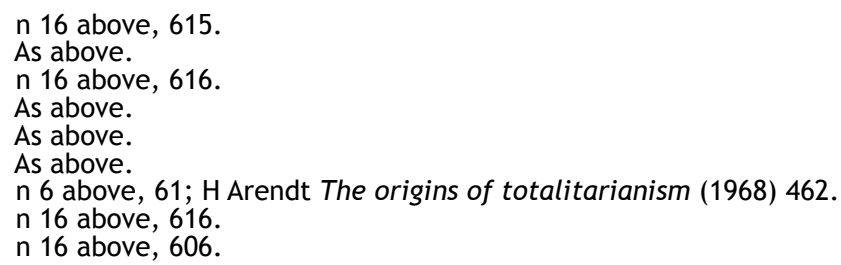


and revolt) 'unnecessary." 44 An example of where human rights do not circumvent hegemonic state power and control and, in fact, support it is the recent service delivery protests, wage strikes and activist efforts against privatisation of basic services in South Africa which are often met with arrests, police brutality, tear gas, water cannons and rubber bullets. Petitioners and demonstrators at international conferences like the G8, the World Summit on Sustainable Development and the World Economic Forum are also met with threats and repressive tactics. By setting the parameters for legitimate struggle so thinly, the struggle theory runs the risk of aligning itself with powerful governments, capitalist interests and elite international agencies and not with poor, disenfranchised and alienated citizens as it purports to do. When political dissent is defined within the confines of the "rule of law", all forms of struggle are negated.

The triumphalism in Heyns' belief that a set of positive laws, a collection of words, rules and promises (going by the name of 'human rights') can bring peace and prosperity, end all struggles and suffering, also causes great uneasiness. Indeed the struggle theory might have resonance and relevance in China or North Korea (and most recently in Tunisia, Egypt and Libya) but in South Africa, it is misleading to make people who are still hungry and homeless believe that human rights will feed them and give them shelter - especially

Heyns (n 19 above) 17. I tend to share much of the uneasiness expressed by Van Marle and also by Isolde de Villiers about the struggle theory and human rights in general. De Villiers, following Jennifer Nedelsky argues that rights are too individualistic, they obfuscate the real political issues at stake and serve only to alienate and distance people from one another (in Heyns' theory, even an individual can claim the right of self-help and more curiously, a judge can rule against a collective majority in favour of a 'longer term' conception of majority). I am interested in the struggle theory because it attempts to redeem law and human rights by moving human rights discourses out of the strict domain of law to an in-between space between 'people on the ground' (politics and the political) and the 'powers that be' (law and legality). But I am sceptical of it because I do not see how it can facilitate or support post-apartheid struggles for dignity, recognition and equality and also why a notion that could be seen as supporting anarchy would simultaneously be tethered to the argument that 'the coming' of human rights makes struggle, contestation and self-help unnecessary. I am concerned at how human passion, struggle and agency is framed strictly in terms of law and human rights. By using Mandela's words 'the struggle is my life' as part of his argument, Heyns seems to be saying that the need for and importance of the legal concept of human rights is what animated the defiance campaign and other revolutionary struggles against the racist apartheid regime, thus negating deeply ethical, political and social dimensions of the anti-apartheid movement. To my mind there is more at stake in any struggle than the eventual entrenchment of a set of rules. Requirements for legitimacy, emphases on rationality and tempered passion and the reliance on western and even Christian history lead me to conclude that the actual summary of the struggle theory is: human rights (sometimes) = legitimate resistance (only if) ... and (but ...). See I De Villiers 'South African legal culture in transformative context', unpublished LLM dissertation, University of Pretoria, 200967 - 76 where the struggle theory is also criticised for falling into the trap of universalism, essentialism and for being reactionary in nature. 
due to the fact that human rights are caught up in the language and jargon of formal rules and legalities. The mathematics of the struggle theory is also disconcerting: the measure taken to resist the infringement of human rights must be proportional and balanced, says Heyns - the two acts (the infringement and the resistance) must (neatly) cancel each other out. ${ }^{45}$

Connected to the uneasiness with the struggle theory, are warnings against formalist and apolitical approaches to law and human rights. Klare warned against this in observing that South African lawyers, academics and judges display a:

... relatively strong faith in the precision, determinacy and selfrevealingness of words and texts. Legal interpretation in South Africa tends to be more highly structured, technicist, literal and rule-bound. ${ }^{46}$

He cautions against this, urging scholars, judges and practitioners to refuse outmoded methodologies and interpretations and rather, to embrace alternative, more critical approaches:

[C]onservatism reduces the transparency of the legal process, thereby undermining its contribution to deepening democratic culture. ${ }^{47}$

[J]urisprudential conservatism ... may induce a kind of intellectual caution that discourages appropriate constitutional innovation and leads to less generous or innovative interpretations and applications of the Constitution. ${ }^{48}$

Refusal, as it is understood here, was born out of those critical points on action, thinking and revolt. It is apt that three years later, Van Marle would formulate an updated critique based on the following words by Patrick Hannafin: 49

The right to refusal calls us to think beyond the state and our role in the biopolitical matrix. It involves a questioning of why it is that the law presumes to be in control of language. It involves a certain refusal to submit to the law, to be insubordinate. It is that other law of writing that is without foundations as opposed to the writing of law, which purports to found the community. It is a call to suspend the dialectical closure of representational politics, as well as the essential complicity of government and legal opposition deriving from it, to affirm a different kind of politics, no longer dependent on the law of possibility.

For Van Marle, at the heart of refusal is the notion of a 'jurisprudence of generosity' as espoused by critical race theorist Patricia Williams, ${ }^{50}$ which could best be exemplified by Mokgoro J's

45

46 above, 32

n 14 above, 168. See also K van Marle 'The spectacle of post-apartheid constitutionalism' (2007) 16 Griffith Law Review 411 - 429.

47 n 14 above, 171.

48 As above.

49 P Hannafin 'The writers refusal and the law's malady' (2004) 31 Journal of Law and Society 14.

$50 \quad \mathrm{P}$ Williams The alchemy of race and rights (1991). 
judgement in the Khosa ${ }^{51}$ case and Sachs J's judgement in Dikoko. ${ }^{52}$ In Khosa the Constitutional Court found that it was unconstitutional to exclude permanent residents (albeit refugees from Mozambique) from the class of persons entitled to a variety of social security grants such as old age, disability, veterans, child-support and foster care grants. The basis for this ruling was tentatively that sections 26, 27 and 28 of the Constitution use the word 'everyone' and 'every child' respectively and that as such, delimiting access to social service grants was a clear violation of the spirit, purport and objects of the Constitution. Emphasising the importance of the State taking responsibility for the Other, Mokgoro $\mathrm{J}$ writes: ${ }^{53}$

The exclusion of permanent residents in need of social-security programmes forces them into relationships of dependency upon families, friends and the community in which they live, none of whom may have agreed to sponsor the immigration of such persons to South Africa ... Apart from the undue burden that this places on those who take on this responsibility, it is likely to have a serious impact on the dignity of the permanent residents concerned who are cast in the role of supplicants.

In Dikoko, Sachs $\mathrm{J}$ took the route Van Marle and Klare seem to be calling for - a risking law that refuses jurisprudential conservatism in favour of more innovative and generous applications of the Constitution. Sachs $\mathrm{J}$ argued that the almost exclusive preoccupation with awarding monetary damages as compensation in defamation cases is incompatible with restoring the damage to a person's reputation and indeed to the parties' relationship. His view is that a defamation law that would rather encourage apology with the aim of reparation, face-to-face public encounter, and reconciliation as opposed to a punitive method would be more appropriate. Sachs J does not aim for an expedient judgment but rather attempts to repair the broken relations between the parties in the hopes that peace and happiness could become a norm in society. It is worth quoting Sachs J when he writes that: 54

There is a further and deeper problem with damages awards in defamation cases. They measure something so intrinsic to human dignity as a person's reputation and honour as if these were market place commodities. Unlike business, honour is not quoted on the Stock Exchange.

We could also turn to Port Elizabeth Municipality $v$ Various Occupiers ${ }^{55}$ for another example of a 'jurisprudence of generosity.' In $P E$ Municipality, the Court refused to grant an order for the eviction of homeless 'unlawful' occupiers of privately owned land on the basis

51 Khosa $v$ Minister of Social Development; Mahlaule $v$ Minister of Social Development 20046 BCLR 569 (CC).

Dikoko v Mokhatla 2007 (1) BCLR 1 (CC). See paras 105 and 113-15.

n 52 above, para 76.

n 52 above, para 109.

200412 BCLR 1268 (CC). 
that the occupiers had been on the land for many years and the municipality had taken insufficient and perfunctory steps to establish the circumstances of the occupiers. The land was also not needed for immediate use by the owners. The Court thus did away with the formalistic common-law right to property and rather chose to recognise the right of the 'various occupiers' not to be arbitrarily deprived of a home. Sachs $\mathrm{J}$ took notice of extra-legal phenomena in his consideration of how, during the apartheid era, illegal squatting would have been met with repression and brutality which not only brought great indignity and iniquity against black people, but also led to the undesirable creation of large affluent white suburbs that coexisted alongside poor black locations marked by poverty, and harsh social conditions. The Court, in a communitarian gesture, was at pains to emphasise that: ${ }^{56}$

[i]t is not only the dignity of the poor that is assailed when homeless people are driven from pillar to post in a desperate quest for a place where they and their families can rest their heads. Our society as $a$ whole is demeaned when state action intensifies rather than mitigates their marginalisation.

These three cases, together with rulings in, inter alia, Bhe, ${ }^{57}$ Fourie $^{58}$ and Makwanyane ${ }^{59}$ show that the Constitutional Court was animated not by a concern with a fixed understanding of dignity and equality or with rigid and technical interpretations. Instead the court focused on uBuntu, respect, intrinsic worth, 'care and concern', happiness, love, the centrality of life, and the reconciliation between 'enemies.' In other words, the courts applied an ethical interpretation of dignity and equality 'unencumbered by rules and doctrine' and paid close attention to the concrete experience and realities that impact on people and play themselves out in the legal arena. When the State said to the plaintiffs in each of the above cases that '[y]ou do not interest me', the Court refused this and acknowledged that 'no [one] can say these words without committing a cruelty and an offending against justice. ${ }^{60}$ It seems that Sachs $\mathrm{J}$ and Mokgoro $\mathrm{J}$ in these judgements also responded to Klare's call for judges to develop a politically and morally-engaged humanist form of judicial decisionmaking.

This body of case law could be said to refute Van Marle's apprehension towards law's ability to address social problems but paradoxically it also emphasises the importance of refusal, generosity and risk as modes of legal enquiry and interpretation. We are then left

56 n 55 above, para 18.

57 Bhe v Magistrate, Khayelitsha, 20051 BCLR 1 (CC).

58 Minister of Home Affairs \& Another v Fourie \& Another; Lesbian and Gay Equality Project \& Others v Minister of Home Affairs \& Others 20063 BCLR 355 (CC).

59 S v Makwanyane 19956 BCLR (CC).

60 See Simone Weil 'On human personality' in R Rees (ed) Selected essays (1962) 934. 
to wonder what the results would have been had a similar ethics and politics and concern for 'enhancing lives' also featured in the cases of, inter alia, Prince, ${ }^{61}$ Volks, ${ }^{62}$ and Jordan. ${ }^{63}$ The critique offered by refusal and its overt concern with politics, ethics and humanity is a useful antidote against narrow, logocentric and universalist theories and approaches. Scholars could employ the notion of refusal in their fight for justice, social reconciliation and transformative constitutionalism. Refusal is thus not passive or quietist, it is active and critical. It also produces tangible results when integrated into legal judgements and research agendas.

\section{Talking refusal - refusal as limit and possibility}

We are always, in a profound sense, guilty of giving too little and arriving too late. Derrida is serious when he writes that none of us is in a position to have a good conscience. ${ }^{64}$

Refusal is of course caught within its own limits. Refusing the pervasive power of positive law and institutionalised human rights does not make them any less pervasive and any less dominant. It merely circumvents their immediate power, subverts their hegemony and opens up spaces for resistance and revolt from where one could find different ways to live under law. This is the wonder and irony of refusal: by being open to its own limits and impossibilities, refusal beckons alternatives, possibilities and limitless opportunities. The notion of refusal then borrows from Drucilla Cornell's 'philosophy of the limit' (her renaming of deconstruction) to show that limits and possibilities share a very special relationship because 'what is other to our present social reality cannot be known in advance and already foreclosed by some grand theory. ${ }^{65}$ In this way, limits open the space for an as-yet unknown future.

Cornell articulates two meanings of limitation, which are suggestive for refusal and for law's potential. Firstly, 'the limit of theoretical reason' in the sense that critical philosophy understands that we can never go beyond current representations of the world as given to us by imagination and secondly, following Derrida, 'the limit of what can be known is also a condition of knowability ...' 66 She recalls Immanuel Kant's three great questions of philosophy - each of

Prince v President, Cape Law Society \& Others 20022 SA 794 (CC), 20023 BCLR 231 (CC).

62 Volks NO $v$ Robinson \& Others 20055 BCLR 446 (CC).

$63 \mathrm{~S} v$ Jordan \& Others (Sex Workers Education and Advocacy Task Force \& Others as Amici Curiae) 200211 BCLR 1117 (CC).

64 D Cornell Moral images of freedom: a future for critical theory (2008) 70.

65 n 64 above, 3.

66 n 64 above, 5. 
which is attached to some tentative hope in the future and the pursuit of an aporetic life: 'What can I know? What am I to do? What can I hope for?'67 For Cornell, hope is something that cannot be proven to be impossible and thus since we can never know what is impossible, we have to always be willing, through reflexive judgement and aesthetic ideas, to imagine and explore what might be possible. ${ }^{68}$ Hope is thus central to the notion of limit. Cornell writes: ${ }^{69}$

Limitation then actually keeps open the impossibility of knowing what is impossible, leaving certain positivistic or naturalistic conceptions of humanity incapable of concretely postulating what we hope to achieve.

An ethic of refusal is precisely aimed at keeping open those possibilities; experimenting with and pursuing them; preventing their closure by reified and uncritical approaches. Many legal scholars have attempted to expose the limits of law to achieve social change ${ }^{70}$ largely due to liberalism's rigid separation of law and politics, citizens and communities, justice and care, rights and rules. The formation and 'becoming' of the Critical Legal Studies (CLS) movement and its critique of law also exemplifies a refusal - of outdated approaches to legal pedagogy. Law students, during the troubled period the world was in when the CLS movement was formed, were clearly struck by the contrast between the law taught to them in the lecture halls and the legal and ideological tensions that were dividing nations around the world.

The gap was too wide and a deeper understanding of the nature and role of law was sought. They focused on the ways that law had contributed to illegitimate social hierarchies, producing domination of women by men, non-whites by whites and the poor by the wealthy. CLS scholars draw upon diverse intellectual currents - ranging from literature, political philosophy and history to Marxism and social theory - in order to expose the indeterminacy of legal rules, the fundamental contradiction in legal discourse and the possible impotence of rights to address social problems. ${ }^{71}$

In addition to exposing law's limits, CLS scholars also opened up the possibilities of new unconventional perspectives. The indeterminacy critique shows that more often than not, a judge (and

67 n 64 above, 4.

68 See D Cornell Philosophy of the Limit (1992). See Woolman 'Book review: Moral Images of Freedom by D Cornell' (2008) 125 South African Law Journal 452.

69 n 64 above, 6.

70 For a comprehensive discussion of law's (in)ability to transform society, see A Kok 'Is law able to transform society?' (2010) 127 South African Law Journal 59 - 83.

71 See C Woodard "Toward a "Super Liberal State": A review of "The Critical Legal Studies Movement” by Roberto Unger' The New York Times 23 November 198627. See RM Unger 'The Critical Legal Studies movement' (1983) 96 Harvard Law Review 561-675; Fitzpatrick \& Hunt (eds) Critical Legal Studies (1987); M Tushnet 'Critical legal studies: A political history' (1991) 100 Yale Law Journal 1515-1544; and MG Kelman A guide to critical legal studies (1987). 
the legislature?) is often confronted with two contrasting options and considerations (encompassing clashing norms and principles). The final choice made by the judge is then closely tethered to her social, political, and ideological predispositions and values and not objectivity and neutrality. Duncan Kennedy explains: ${ }^{72}$

First, each argument is applied, in almost identical form, to hundreds or thousands of fact situations. When the shoe fits, it is obviously not because it was designed for the wearer. Second for each pro argument there is a con twin ... Although each argument has an absolutist, imperialist ring to it, we find that we are unable to distinguish particular fact situations in which one side is more plausible than the other. The difficulty, the mystery is that there are no available metaprinciples to explain just what it is about these particular situations that make them ripe for resolution. And there are many, many cases in which confidence in intuition turn out to be misplaced ... The ultimate goal is to break down the sense that legal argument is autonomous from moral, economic and political discourse in general.

The 'fundamental contradiction' thesis shows the inherent tension in law and society between individualism and altruism (that neither can offer a comprehensive vision of social and political life) and between form and substance. It also highlights some of the limitations that bedevil contemporary (or modern) legal thought. CLS scholars have forced legal academics and practitioners to accept the 'fundamental contradiction' thesis and to

... grapple with the complex links between law and structural constraints imposed on it by contingent dynamics in the state, economy, and culture - links often concealed by liberal visions legal formalism, legal positivism and even much of legal realism. ${ }^{73}$

So to where do we turn for a politics and ethics of refusal, critique and a risking law in the face of a conservative legal culture, a law that is far too blunt and too limited to achieve the goals of the Constitution and academics who refuse to accept or engage with theses like indeterminacy and fundamental contradiction? As earlier noted, refusal is a concept that focuses simultaneously on limits and on possibilities. We could then hope only to recall the aporetic moments of the Constitution and the utopian ideal embedded in it which will always be deferred, always be in a state of 'not-yetness' and always remain caught in its own limits, its own impossibilities. Douzinas is indeed correct to say that 'the end of human rights comes when they lose their utopian end ...' ${ }^{74}$ Douzinas notes: ${ }^{75}$

72 D Kennedy 'Form and substance in private law adjudication' (1979) 92 Harvard Law Review 1685 - 1778.

C West 'CLS and a liberal critic' (1988) 97 Yale Law Journal 757.

n 34 above, 380.

C Douzinas ‘Human rights and postmodern utopia’ (2000) 11 Law \& Critique 200 239. 
While like all utopians its realisation is always deferred, turning human rights from governmental triumphalism and diplomatic somnambulism into utopian hope would be the greatest contribution of our political culture to the new millennium.

By using narratives, stories, and allegories, the utopian imagination projects a future society and keeps it in abeyance, held together only by hope and uncertainty. This is a better response to a pessimistic, defeatist account of law's ability to restore, repair and reconcile and of the possibilities for meaningful change in the lives of people who remain marginalised by the structural inequalities and oppressive realities that haunt their gender, race, ethnicity and class. Refusal thus revives utopian thinking and upholds the transformative ideals of the constitution and human rights discourse while also being vigilant of the pervasive formalism dominating analytic jurisprudence.

Utopian thinking is open to multiple versions and meanings of reality. For that reason, it is an approach that resists the imposition of one definite, irrefutable version and expression of reality and rejects the notion of one "central truth. ${ }^{, 76}$ Cornell adds: 77

Utopianism has always been tied to the imagination, to visions of what is truly new. A new world in which we could share life's glories would be one radically different ... At last it is up to us to turn yesterdays' utopia.

\section{Doing refusal - refusal as/and the performative}

The notion of refusal could be well served by a brief recollection of Judith Butler's well-known idea of 'gender as performative."78 In short, Butler's point is that when women (as a special example) act and speak in a certain gendered way, they are not merely reporting on or performing something that is already fixed and immutable, they are in fact, actively constituting it, replicating it, and reinforcing it in the world. By behaving as if each sex has specific 'natures' and 'characteristics', the social fiction that these natures actually exist is actualised and reproduced. These social norms or power structures are never isolated or given - they exist by virtue of our affirming acts. Butler shows us that by continuously citing and conforming to the conventions and ideologies in the social world around us, we not only

$\mathrm{K}$ van Marle 'In support of a revival of utopian thinking, the imaginary domain and ethical interpretation' (2002) Journal of South African Law 501.

77 Cornell At the heart of freedom: feminism, sex and equality (1998) 186.

78 See J Butler Gender trouble: feminism and the subversion of identity (1989) and the follow up, Butler Bodies that matter: on the discursive limits of 'sex' (1993). 
enact that reality, we create it. We make social constructions like gender (and race) seem natural and necessary. ${ }^{79}$

Conversely, and this is where refusal comes in, by carrying out these behaviours, attitudes and gendered performances in a somewhat different manner, through parody and subversion, we can perhaps unmake them and in the process, redefine the norms, rules, narratives and meanings that control our lives. The wider notion of refusal as an act discloses possibilities for problematising dominant assumptions, hegemonic power structures and stereotypical roles ascribed to and forced upon, among others, women, black people and homosexuals on a larger scale. With this Butlerian insight, refusal could be connected to Kristeva's notion of 'revolt'. Kristeva finds that the term 'revolt' suggests political action and human agency because of its 'etymological association with return, patience, distance, repetition, elaboration.' 80 'Revolt is not simply about rejection and destruction; it is also about starting over' - it 'foregrounds an element of renewal and regeneration. ${ }^{81}$ Kristeva regards (the liberty to) revolt to be fundamental. For her, neither a life of thinking, nor a life of sociality, is possible without it. She adds that she is referring to " "life" here, and not just maintenance, repetition, management.'82

A succinct definition of the hegemonic order that the notion of refusal is set up to oppose and displace - to revolt against - is provided by Jean Comaroff and John Comaroff: ${ }^{83}$

[T]hat order of signs and practices, relations and distinctions, images and epistemologies - drawn from a historically cultural field - that come to be taken for granted as the natural and received shape of the world ... This why its power has so often been seen to lie in what it silences, what it prevent people from thinking and saying, what it puts beyond the limit of the rational.

Davis and Le Roux introduce the concept of 'lawfare' in their discussion on the use and abuse of law. Relying on the Comaroffs, ${ }^{84}$ Davis and Le Roux observe that as law becomes the primary instrument for structuring society, the targets of state power (i.e. citizens) invoke human rights to defend their freedom, privacy and personal sovereignty against attempts to use the law as a form of social control. To be clear, citizens thus refuse attempts by the state to emboss its authority and control over them through the medium of

Butler 'Performative acts and gender constitution: An essay in phenomenology and feminist theory' in S Case (ed) Performing feminisms: feminist critical theory and theatre (1990) $270-272$.

J Kristeva Revolt, she said (2002) 123.

As above.

n 80 above, 12 .

$\mathrm{J}$ Comaroff \& $\mathrm{j}$ Comaroff Of revelation and revolution: christianity, colonialism and consciousness in South AfricaVol 1 (1991) 23.

$\mathrm{J}$ Comaroff \& J Comaroff (eds) Law and disorder in the postcolony (2006) 26-27. 
law. ${ }^{85}$ The concept of 'lawfare' can be described as 'juridicalisation of politics' or the 'politicisation of the courts' - when citizens and communities take their struggles to the courts. ${ }^{86}$

Courts in some very tentative way could serve as the stage and battleground for refusal where the rights of people with HIV/AIDS to antiretroviral treatment can be claimed, ${ }^{87}$ where homosexuals can fight for recognition and dignity ${ }^{88}$ and where mourning families can refuse to accept that the TRC granted amnesty to the killers of their loved ones. ${ }^{89}$ The concern in this section is with practical, reformoriented and activist projects grounded in an ethics of refusal. It is also concerned with those subversive and parodic acts of resistance that so subtly challenge the established order. It is trite that the most obvious act of refusal and resistance is civil protest, especially that conducted by social movements. As Ashwin Desai and Richard Pithouse note, 'revolts have ebbed and flowed in poor communities all over the country since 1996.' 90 Patrick Bond points out that 'the pace of social protests intensified dramatically during the mid-2000s soaring from 5,813 recorded protests in 2004-05 to more than 10,000/ year'. ${ }^{91}$ Tshepo Madlingozi connects the notion of refusal with Michael Neocosmos' conception of an active citizenship that 'refuses the technicisation of politics as well as the passivity engendered by ... an over-reliance on human rights. ${ }^{\prime 92}$

Madlingozi raises the point that many community organisations, including Abahlali base Mjondolo, the Treatment Action Campaign, and the Anti-Privatisation Forum have enacted their own politics of refusal through activism against the onslaught of privatisation, poverty, neo-liberal policies like GEAR as well as the slow realisation

$P$ Bond 'Rejoinder: collaborations, co-optation \& contestation in praxis-based knowledge production' (2008) 35 Review of African Political Economy 272. Following on earlier critiques, the struggle theory would not have facilitated the civil society protests and labour strikes because the struggle theory speaks to blatantly unstable and despotic states. Refusal on the other hand is specifically about acting and revolting against pervasive and deceptive attempts to circumvent human agency through law and constitutional patriotism irrespective of whether there are strong governance mechanisms and human rights instruments.

9

T Madlingozi 'HayiBo! refusing the plan - acting, thinking and revolting by postapartheid social movements and community organisations' in K van Marle (ed) Refusal, transition and post-apartheid law (2009) 82. 
of socio-economic rights. For Madlingozi, it is 'bottom-up' types of politics exemplified by these movements that are at the heart of refusal and revolt in the post-apartheid State.

The presence of social movements, civil society and community organisations adds to the view shared by some that Van Marle could have overstated her argument that the enthusiastic embrace of human rights law has lead to a complacent society in which 'political action, thought, eternal questioning and contestation are absent and replaced by an understanding of freedom as mere commercial/ economic freedom and of thought as calculated and instrumental ... ${ }^{93}$ Madlingozi calls for critical theorists to refuse the bureaucratisation of political action and the 'robotisation' of life and thought' and for refusal to be linked with activism. ${ }^{94}$ The notion of refusal thus needs to be widened to accommodate acts of refusal such as COSATU-led labour strikes, civil society marches for women's rights and service delivery and the work of post-apartheid social movements in order to articulate South African society more fully and accurately.

It is useful to recall Patrick Hannafin and his evocation of Maurice Blanchot's act of refusal. Blanchot was the main drafter of the Declaration of the Right to Insubordination in the Algerian War (Manifesto of the 121). ${ }^{95}$ Hannafin notes how Blanchot called for the 'absolute right to refuse to accept' the state's contention that the French colonial war in Algeria was executed in the interests of the people. In the process of drafting the Manifesto, Blanchot also had many concerns namely, 'the contest between law and its other'; 'the play between power and transgression' and the ethics of 'responsibility' 96 for other human beings. The declaration in effect was a refusal of the way in which 'legal language taxonomises the subject' 97 and thus established the right to refuse to take up arms and go to war against the Algerian people - a right which was not granted by law or justified through any moral code (in short, a right to defy the state). The State then initiated criminal proceedings against all the drafters of the Manifesto. Blanchot enacted his own ethic of refusal when he objected to the magistrate summarising his statement instead of allowing him to give a testimony. Blanchot's act(s) of refusal exposes the 'fragility', rigidity and 'mortality' of law

93 n 2 above, 196.

94 n 92 above, 89.

$95 \mathrm{n} 49$ above, 3. This is again indicative of the interplay between the claims of the struggle theory and the objects of refusal. The Declaration was effectively also a codification of the right to self-help (that is, the right to ultimate refusal - to refuse to abide by state laws in favour of justice, freedom and dignity and to refuse 'to submit to law' (through state power), 'to be insubordinate').

As above.

97 As above. 
and is also indicative of the need for action, thinking and revolt to be central to the notion of refusal and to post-apartheid legal theory: ${ }^{98}$

I signed this text ... as an apolitical writer who felt moved to express and opinion about problems that concern him essentially ... One of the main purposes of the Declaration is to bring about the particular responsibility of intellectuals: when the democratic order is corrupted or decays, it falls to them, independent of any purely political allegiance, to say in simple terms what seems to them just.

Indeed the act of refusal is subversive and transgressive, disruptive and interruptive, idealistic and irreverent - located in a liminal, inbetween space, a precarious and volatile temporality. Drawing from the world of art, let us recall one more example of refusal in the aesthetic portrayal of Justitia, the goddess of justice.

According to Martin Jay, Justitia was originally a seeing maiden until the end of the 15th century, when a blindfold covered her eyes. ${ }^{99}$ He explains how, what was actually a satirical addition, had, by the mid-16th century, become a deeply entrenched narrative of the official legal discourse. This suspect new image of 'blind justice' corresponded with other changes that occurred in the legal sphere: the removal of artworks and illustrations from courts and law books, and judges wearing dull black and white robes - essentially killing the spirit of law. These changes in legal culture, connected to the spread of Enlightenment thinking and the rise of the secular, urban bourgeois culture, can be attributed to the rapid rise of science, logic, rationality and abstraction as the only acceptable modes of thought and reasoning in Western modernity.

Jay reads the blindfold of Justitia as an effort to mask the intuition and perceptiveness associated with the feminine, cunningly to ensure that the dominant hegemony was also extended into law. These changes all sought to eliminate any concrete or bodily attachments from law, which, for the purposes of legal theory, symbolise what Jay calls 'the modern cult of the abstract and determinant norm of legal formalism ...' 100 The new paradigm of impartial, objective and strict justice led to a bombardment of statues and fountains depicting a blindfolded Justitia and subsequently reified this image as law, resulting in the rejection of all visualisations, values, voices and visions that differ from this 'certified' idea of law.

Just as refusal calls for us to displace the fundamentalist belief in scientific foundations and (common law) classifications as the only

98 n 49 above, 7. See M Blanchot 'The right to insubordination' in M Holland (ed) The Blanchot reader (1995) 196.

99 M Jay 'Must justice be blind? The challenge of images to the law' in C Douzinas and L Nead (eds) Law and the image: the authority of art and the aesthetics of 100 law (1999) 19 -35.

n 99 above, $23-24$. 
way of doing law, so should the traditional image of a blind (unseeing and uncaring) Justitia be challenged and refused. As Van Marle suggests, we should focus on the energy of resistance provided by the black, naked, seeing Justitia drawn by artist Braam Kruger that appeared on the posters from the University of Pretoria Centre for Human Rights promoting the first human rights conference in the late eighties - a time when apartheid was at its height. ${ }^{101}$

The first act of refusal was the persistence with which the Centre for Human Rights itself was formed against the backdrop of a historically white Afrikaner University and a Faculty of Law that was trapped by the dogmas of judicial avoidance, positivism and the common law - with some colleagues at the time even suggesting that human rights was not a 'legal discipline' and hinted of 'politics'. The second act of refusal was daring to host a conference on human rights in a society where the law confirmed the claim that only white people were human beings and black people were sub-humans subjected to the worst forms of subjugation, brutality and oppression.

The third and most subversive act of refusal was indeed the image of a black woman being projected as the goddess of justice in light of the position of blacks and women at the time. Not only was the blindfold removed to embrace a conception of justice based on care and paying attention to the material conditions, needs, experiences, and fears of human beings. It also depicted a black woman - a victim of both white supremacy and patriarchy - as the ideal representation of justice. This image remains a suspensive utopian ideal keeping alive the hope that, one day, black women will be intrinsically worthy of respect and free of domination and misery, equal with whites and men.

\section{Conclusion}

To bring to light the singular character of this refusal is one of the theoretical tasks of the new political thinking. This theoretical undertaking obviously does not entail drawing up a programme or a platform, but rather, independent of any programmatic project, indeed of any project, maintaining a refusal that is an affirmation, bringing out or maintaining an affirmation that does not come to any arrangements, but rather undoes arrangements, including its own, since it is in relation with dis-arrangments or disarray or else the non-structural. ${ }^{102}$

Let us return to three related moments in this article: 'refusal as critique' is a counter-hegemonic disruption to the business-as-usual

$101 \mathrm{~K}$ van Marle 'Meeting the world halfway - the limits of legal transformation' (2004) 16 Florida Journal of International Law 662. The artwork is entitled 'Anna Mongale as Justitia' (1989).

102 M Blanchot 'Affirmer le rupture' in M Holland (ed) The Blanchot reader (1995) $200-201$. 
approaches to law and politics. I have argued that refusal as an ethical notion can challenge judgements concerning people's wellbeing to be more generous (by being attentive to complexity, particularity and context) and force lawyers and legal scholars to take up the challenge of transformative constitutionalism. The ethics of refusal not only says 'no', it asks 'why' and 'why not' but never says 'never'.

In 'refusal as limit and possibility' I suggested that by engaging with the limits of law, refusal opens law to new possibilities and unpredictable directions. Refusal thus calls for keeping the utopian promise of the Constitution alive. 'Refusal as performative' recalls our complicity, responsibility and agency. As subjects within a more totalising system of power and domination, we must - like postapartheid social movements, the black Justitia, and Blanchot - enact refusals and resistance(s) intended to displace the hegemonic orders of patriarchy, racism, neo-liberalism, capitalism, and repression. Refusal in its performative mode is an active and audacious politics connected to the words of Bartleby, 'I would prefer not to'103 and does not merely imply bystanding, compromise or standing back.

Throughout this essay I have attempted to demonstrate that the act and ethic of refusal is a decidedly unorthodox approach to conventional law and human rights. Refusal urges a critical distance from the mainstream and underscores the necessity of a critical and thoughtful engagement with the complexities and vagaries of law, politics and society within the context of shifting South African realities.

That refusal cannot be situated, categorised or systematised under any specific normative theory of or approach to law is one of its most defining features and indeed, what makes it truly path-breaking. By asking the questions that should vex any serious legal scholar: What is law? What exactly is so special about law? What can and can't law do? And, following Aristotle, what role can law play in creation of the good society? Van Marle pushes us to embrace refusal as a mode of critical thought in the face of thoughtless, instrumental and calculated accounts of law, virtue, justice, community and ultimately, life.

Specifically in a post-apartheid context, it is crucial that we embrace alternative approaches to law and human rights. The significance of refusal is that it marks a decisive objection to the business-as-usual approach adopted by lawyers, judges and academics that continue to remain prevalent, even after the major constitutional changes that occurred in our country since the early 
1990s. The problem with this approach is that it entrenches conservative and traditional practices in the South African legal culture and excludes all voices that are different from this comfortableness. The continued belief in scientific classifications and old-school legal thinking is both counter-productive and inefficient. If we are indeed to cultivate an active politics and democratic culture, we cannot uncritically genuflect to the promises of the Constitution in the form of formal law and institutionalised human rights. The politics and ethics of refusal turns away from 'traditional ways of thinking and doing law' and openly accepts the 'unexpectedness that breaks with the formality and predictability of law.'

I would like to conclude with a final note of candour: Of course, the notion of refusal and much of the scholarship that shares its ideals and works from similar paradigms (such as postmodernism, CLS, aesthetics, law and literature) have constantly come under the hackneyed criticism that they are too 'idealistic'; 'irrelevant'; 'obscure' and 'abstract.' These writings are regularly accused of over-theorising and over-philosophising at the expense of issues and efforts that fall within the ambit of 'real work' and 'real law' often because they engage with art and literature rather than, or more than, case law and legislation. In other words, they opt for critique rather than technical analysis. To my mind, the pressures and demands for all 'legal' research to prove practical relevance and immediate success operate from the static reading of law as neutral, apolitical and fixed. Questions concerning the politics of law, the limits of law, the possibilities of law and their connection to everyday life and the nuanced differences and complexities of living cannot be separated from research, teaching and practice in law, from the 'real work' and from 'real law'. ${ }^{104}$

The artificial dichotomy between theory and practice and between philosophy and reality negates three critical points. First, the loaded, contingent and normative nature of 'law' itself: that it is not set in stone but can be changed, challenged and re-imagined. Secondly, that philosophical reflections and theoretical multidisciplinary research often serve as the groundwork for litigation and activism, but the two are still qualitatively different and neither claims the role of the other. Thirdly, and most importantly, academic thinking and research within a university should not merely be

104 The debates arising out of these criticisms are explored in various writings - most notably in $\mathrm{n} 13$ above, 297; 'Jurisprudence, friendship and the university as heterogenous public space' (2010) 127 South African Law Journal 645; W Le Roux \& K van Marle 'Postmodernism(s) and the law' in C Roederer \& D Moellendorf (eds) Jurisprudence (2004) 354; D Davis 'Duncan Kennedy's A Critique of Adjudication: a challenge to the "business as usual" approach of South African lawyers' (2000) 117 South African Law Journal 697; J van der Walt 'The quest for the impossible, the beginning of politics: a reply to Dennis Davis' (2001) 118 South African Law Journal 463. 
functionally applied as an instrument but also as a constant engagement with complexity, academically multiple possibilities and with a 'politics of the future.' The charge that such work is produced by 'ivory-tower academics' in their 'air-conditioned offices' is, contrary to its claims, part of efforts at gate-keeping and regulating legal thinking. This limits possible theories and excludes critical voices rather than expanding and exploring the ways in which the law can indeed be an instrument and source of social change, justice and ethics. For that reason we should be sceptical of instrumental reliance on rational knowledge and significantly break away from traditional and unreflective approaches and perspectives as they could lead to misdirection in our efforts to positively transform the human condition. Life demands more. People deserve better.

I just do things

The mob has plans. The cops have plans. Gordon's got plans

You know, they are schemers

Schemers trying to control their little worlds

I am not a schemer

I try to show the schemers how pathetic their attempts to control things really are ... 